\title{
UNDERSTANDING EDUCATION OF AUTHORITATIVE ISLAMIC LAW PERSPECTIVE KHALED ABOU EL FADL
}

\author{
Choirul Mahfud \\ Institut Teknologi Sepuluh Nopember (ITS) Surabaya \\ Email: choirul.mahfud@its.ac.id
}

\begin{abstract}
Problems with Gender-biased Islamic law education and authoritarianism in the United States have invited the anxiety of prominent Muslim intellectual, Khaled Abou El Fadl. In his book on the Speaking in God's Name, Khaled revealed a crucial hermeneutic problem related to the relation of text (text), author (reader). Khaled also revealed the problem of abuse of "authority" in Islamic law that surfaced and was unavoidable among individuals and groups. Evidently, there are a number of religious fatwas not speaking "about God", but acting and speaking "in the name of God". The focus of this paper further discusses what are the hermeneutical problems in Islamic law education discussed by Khaled Abou El Fadl, and what is meant by the issue of authority and abuse, the relation of text-author-reader, and authoritarianism and its implications in the study of Islamic law. Then what are the mechanisms and methods for formulating the right Islamic fatwa.
\end{abstract}

Keyword: Islamic Law, Authority, Authoritarianism and Fatwa.

\section{INTRODUCTION}

The issuance of a number of Islamic Law Fatwas that are gender-biased and authoritarianism from the Permanent Council for Scientific Research and Legal Opinion (CRLO) in the United States, and may also have occurred in other world regions, causing intellectual anxiety. Different but the same, it can be happened anywhere, including in Indonesia.

According to Khaled, some of the fatwas of Islamic law regarding women that are considered very problematic include: Islamic religious fatwa regarding the use of bra, prohibition of women visiting the tomb of their husbands, women raising their voices in prayer, women driving or steering their own cars, women must be accompanied by the mahram man. For Khaled, 
as revealed by Amin Abdullah, that the fatwas constitute a degrading act not to call them oppressive women that cannot be tolerated in the current era. Fatwas which take refuge under the text claim that that is actually "desired by God". Amin Abdullah explained that Khaled asked "if the men are morally weak, why should women suffer? " If men are indeed weak, why should they also lead the family and country?

Likewise religious opinions or fatwas say that women must pray or perform prayers in the most hidden places, invisible to the view, or women must surrender their entire souls to their husbands whenever their husbands want them, or women's safety is very dependent on satisfaction or the desires of husbands, or women will fill most of the places available to residents of hell, all of which are considered by the author as offensive-oppressive and degrading to women who are morally unfounded.

In more detail, Khaled also showed a crucial and fundamental hermeneutic problem related to the relation of text (text), author (reader) and reader (reader). Not only that but Khaled also critically revealed the problem of abuse of the "authority" of Islamic law that surfaced and was unavoidable among individuals and religious groups. Evidently, many religious fatwa products are not talking "about God", but rather talking and acting "in the name of God". As a result, social- religious problems are not solved by the principle of completing "problems without problems", but because of the interests of certain individuals or groups, solving problems turns out to be a problem.

Furthermore, Khaled also criticized that the study of Islamic law or sharia is considered a final product, closed from studies and even claims. Though it should be understood as an open process and interpretation methodology, and research. Because, sharia in the eyes of Khaled, is a process, methodology and morality where the speaker speaks of the beauty of God's values. Therefore, Khaled argues that Islamic law is a work that continues.

\section{BIOGRAPHY OF KHALED ABOU EL FADL}

Khaled Abou El Fadl is Professor of Islamic law at the University of California Los Angeles (UCLA), United States. He was born in Kuwait, 1963. His educational background is in Egypt and America. In addition to teaching, Khaled is also a Law, Human Rights activist and serves as the Director of Human Rights Watch and Commission on International Religious Freedom) in America. In recent years, Khaled has issued many fatwas as an alternative to the CRLO version of the Islamic law fatwa. Some of the fatwas of Khaled Abou El Fadl can be accessed via the website: http://www.scholarofthehouse.org/onwolepr.html/. 
Khaled was born to a simple, educated family. His parents are devout Muslims who are very open in the field of thought. He admitted honestly, that in adolescence, he was involved in the puritanism movement which was indeed fertile in its environment. His days are filled with utopias about a 'best group' and 'group representing God' on earth. Besides that, every time he met with people, he conveyed the teachings of puritanism which he considered most correct. It was felt that some of his teenage years had been sucked away by puritanic dreams which made him hate, closed, and angry with other people outside his group.

Fortunately, Khaled has pious and learned parents. They offer various treasures of Islamic scholarship from various schools to Khaled. Understandably at that time Wahhabism which became a state school had sorted out all the readings that must be read by the public. The ruler who has an interest in the ideology of Wahabism determines which reading is healthy and unhealthy for the community. With the extensive reading of the Islamic tradition and family support, Khaled began to realize the existence of contradictions and acute problems in the ideological construction and thinking of the Wahhabis. Their claim to many problems is contrary to the spirit of the past scholars in viewing Islam.

Hasan Basri Marwah revealed that the awareness of the importance of openness in thought was increasingly developed when he finally settled in Egypt. In the land of the Pyramids, space is not too crowded as it did in Kuwait. According to him, a repressive and authoritarian system of power will never give birth to the advancement of intellectual thinking or enlightenment for its people. But the shadow of puritanism never dimmed in him. When taking further education at Yale University, the United States to attain a BA (Bachelor of Art) anxiety about Islamic puritanism continues to be an indelible burden. But learning tasks suck up their energy. After Yale in 1986, Khaled went to the University of Pennsylvania which was completed in 1989. In 1999 he continued to Princeton University with a specialization in the field of Islamic Studies which at the same time he had to take law studies at UCLA. Finally, at UCLA he also built a graduate career in Islamic Law. During his lecture, Khaled had time to become a Registrar in the Arizona State Court. He also became a legal practitioner in immigration and investment law matters. In addition to teaching and becoming a professor of Islamic law at UCLA, Khaled is also known as a prolific/ productive writer.

In general, Khaled's thoughts in one of his books are entitled: Speaking in God's Name explaining the issue of Islamic law, authority, and women. In the delivery, Khaled Abou El Fadl explained that the methodology used in writing his book was an analytical and normative method. Khaled also emphasized that 
he was an insider in reviewing and writing books about the study of Islamic law.

In this context, Hujair Sanaky in his article entitled "The Idea of Khaled Abou El Fadl About the Problem of Authoritarianism in the Religion's Interpretation of the Hermeneutic Approach in the Study of Fatwa-Fatwa of Religion" states that Khaled Abou El Fadl placed himself as observing the "Islamic legal tradition". Khaled Abou El Fadl believes in the authenticity of the Qur'an as God's revelation and in the prophethood of Muhammad. But on the other hand, Abou El Fadl also believes that the methodology of "authoritarian" interpretations will undermine "the integrity of Islamic texts", dim his voice and can erode the usefulness of the power of Islamic law. From this rationale, Sanaky considered that Abou El Fadl offered a proposal to uphold the "authority of the text" and limit "authoritarianism of readers".

Uniquely, Khaled Abou El Fadl also offered new things in writing this book. Namely, how to approach and examine the issue of religious fatwa through a deep and sharp hermeneutic approach. Then, in writing this book, Khaled Abou El Fadl also emphasized his position, not as a "social scientist" who only observed, observed and described various tendencies. But its position, as a "legal expert" who seeks to assess the doctrines adopted by the legal community and seeks to provide input to achieve normative progress. During this time, the approach used by Khaled in understanding Islam, namely: linguistic, interpretive social science, literary criticism, as well as standard Islamic sciences from mustalah al-hadis, rijal al-hadis, fiqh, interpretations, later kalam combined with contemporary humanities.

\section{AUTHORITY IN ISLAM}

According to Khaled Abou El Fadl, the anxiety that needs to be parsed first is a matter of authority and abuse. In the Large Indonesian Dictionary, the authority is defined as the right to act; power; or authority. From this it can be understood that authority is the ability to make other parties do something or not do something in accordance with the wishes of those who have authority.

According to Hasan Basri Marwah that in the Islamic tradition, the Holy Text (al-Qur'an) is a representation of 'authority' (authority) of Allah SWT, God Almighty. No one ignores the Scriptures. A sincere Muslim always refers to his Scriptures when facing problems in his life. When he was alive, the Prophet was seen as the most authoritative person, having credible conditions, to interpret all of God's will. The authority or authority of the Prophet is stated in the Qur'an. In addition, his authority was also reflected in his behavior and moral vision that reflected in his life. 
After the Prophet died, continued Hasan, the Qur'an and notes on all dimensions of the Prophet's life became a reference for adherents of Islam. These two sources to this day are still the main reference in the life of Muslims. But problems are not resolved at this point. The question is whether the two texts speak for themselves? Can these two sources solve human problems themselves? After the death of the Prophet, said Hasan Marwah, friends with high moral integrity get authority or become a source of reference in understanding the intent and will of Allah SWT. The authority of friends is more seen by their moral integrity, as shown by Abu Bakr or Umar bin alKhattab. The political crisis and the storm of change are getting stronger and faster among Muslims. After the death of these authoritative friends, political power took over authority arbitrarily. The ruling Mua'wiyah said that he had the authority that had been possessed by the Prophet and his friends. At that time, a number of scholars had begun to appear in various regions of the Muslim community. They usually reject the political titles offered. The overwhelming political power made the scholars more cautious in taking a stand. On the one hand they feel they have a responsibility for society and religion, on the other, hand they continue to be pressured by the power to legitimize their power.

Another example, for example, was when Caliph al-Manshur asked Imam Malik to make his book al-Muwatha, he refused, because he was sure that many would not be in accordance with the opinions of other scholars in various other regions. Imam Malik's attitude shows high integrity, muru'ah, and a tolerant attitude towards differences. And according to Khaled Abou elFadl, behind the rejection of Imam Malik it was implied, that the position of a fuqaha was as a mediator, bridge, or mediator between various interests in the Muslim community. Imam Malik also showed that a cleric should not be coopted by political power. Thus it is very clear, that the 'authority' of a scholar or intellectual is very much determined by the reflection of morals, the integrity of his personality, and his independent attitude. Khaled said, that the 'authority' of an ulama is very much determined by honesty, sincerity, wholeness, and rationality.

In this context, Khaled Abou El Fadl explained the authority by distinguishing its nature. That is a coercive authority and persuasive authority. Coercive authority interpreted as trying to drive the behavior of others by means of force, threats, taking advantage, or punish. This makes people who have common sense will conclude that for practical purposes they have no choice but to obey. While persuasive authority involves normative power, namely the ability to direct one's beliefs or behavior on the basis of trust. This

5 | MODELING, Volume 6, Nomor 1, Maret 2019 
persuasive authority influences people to believe, act, or not act through persuasion.

Borrowing the terminology of RB Friedman, Khaled distinguishes between being in authority and being an authority. According to Friedman quoted by Khaled El Fadl, "assuming authority" means an authority is obtained by structural positions and tends to force others to accept the authority. In this case there is no known "submission to personal decisions". Because, someone can differ in an opinion by taking authority, but has no choice but to obey. Whereas "authority holder" is an authority obtained without structural and coercive positions, but because of a person's capability and acceptability which ultimately raises the awareness of others to accept it. Khaled Abou El Fadl also quoted Hannah Arendt (expert on banality studies) who made the difference between authority and persuasion. For Arendt, as quoted by Fadl, authority is not in line with persuasion. Fadl continued, the authority in Hannah Arendt's eyes was what made people agree without being asked to agree.

Using this theory of authority, Khaled Abou El Fadl tried to construct the idea of stakeholders and authorities in Islamic studies. In the construction of the concept of Islamic authority as a form of bridging God's will, Abou El Fadl noted the following three things: First related to "competence" (authenticity). Second, related to "meaning setting". The third relates to "representative". These three issues, according to Abou El Fadl, play an important role in forming "authority holders" in Islamic studies.

In the history of Islam, around the second century H / 8 AD, there has actually been a very strong and extraordinarily strong candidate for authority to become a competitor of God's law which was formed, presented and presented by certain professional groups known as fuqaha (lawyer). But after the development of the book of Jurisprudence and the legal culture of a technical nature with language, symbols, and specific structures, Islamic law became the representative of an established institution. From a socio-historical perspective, Islamic jurists have become exclusive spokespersons who have "authoritative legitimacy" throughout Islamic history. Their legitimacy is placed in the "corridor of legitimacy" in the history of Islam - both political, communal, customary, ethnic, military and military legitimacy and are incorporated into organized Sufi societies based on a vision and mystical truth.

Khaled Abou El Fadl stated that their legitimacy was based on the ability to read, understand and interpret "God's Will" revealed in a text or passage that was seen as an embodiment of God's Will. God's will (authors) is recorded and may be hidden in the text and jurists (readers) are tasked with finding and studying it. Islamic jurists are very creative and adept at using this as a tool that allows them to go beyond the text itself and they still respect the 
sanctity and value of a text. The jurists often supported legal doctrines that limited the power-without-requirements of the authorities. For example, their views on human rights are owned by individuals and the authorities do not have the power to revoke their rights.

Islamic jurists have played a fairly dynamic bargaining role. They act as a liaison between various social and political structures of society. They can alliance with the government and on other occasions alliance with social forces. That can be said that Islamic legal culture is semi-autonomous. But the jurists did not "make claims" that were assertive as "authority holders" (representing God's will), even though they claimed to be defenders of God's law. Abou El Fadl said that one of the most obvious manifestations of the sad reality of Islamic law is the rise of "authoritarianism" in contemporary Islamic legal discourse. Normative premises that develop the classical Islamic legal tradition no longer exist and the classical Islamic legal tradition that upholds the "premise" of "anti-authoritarian" law formation has died and similar premises are no longer applied in the Islamic legal tradition lately in the modern era and postmodern era. For this reason, Abou El Fadl sharply highlighted the mechanisms for formulating and making decisions on fatwas issued by individuals, community leaders, religious institutions and organizations in general.

Abou El Fadl's question is the basic "competence" that must be possessed by a person, organization or religious institutions that act as a "sole interpreter" and at the same time an executor of God's command. Khaled Abou El Fadl stated that authoritarianism used refers to an ahermeneutic methodology that seizes and subdues the mechanism of the search for meaning from a text into a very subjective and selective reading. Abou El Fadl emphasized that the selective subjectivity of authoritarian hermeneutics involves the similarity between "author's intent" and "reader intent", looking at textual intent and "text autonomy" as secondary. So by assuming textual intentions to be insignificant and to remove text autonomy, a subjective reader will certainly make misinterpretations or cheats and violate. What the interpreter voices is then considered and accepted as "God's voice" himself. There, said Abou El Fadl, religious leaders no longer talked about God, but speak "in the name of God".

\section{authority, authoritarianism, and text relations}

Khaled M. Abou El-Fadl quoted Mohammad Arkoun as arguing that Islamic culture always questioned "unthought" and "unthinkable". However, Khaled has his own category that is different from Arkoun. Namely, "forgotten".

7 | MODELING, Volume 6, Nomor 1, Maret 2019 
This means that what Muslims forget is mainly related to the methodology of Islamic studies.

Furthermore, Khaled also revealed that the problem of authoritarianism or the arbitrariness of readers has been carried out by some individuals or religious groups without regard to the rules of methodology for making legal decisions that have been carried out by classical scholars. The clerics, continued Khaled, easily issued fatwas on every issue they faced regardless of universal values. The fatwas submitted were also monolithiclinear and insensitive to the development of the ummah. The cleric said that one does not need to think about things like that, just say gender or Islamic religious fatwas about women.

The most important breakthrough presented by Abou El Fadl in his efforts to explore "something that has been forgotten" is to restore the identity of religious authority (read: "competence/ authenticity", "meaningful determination", "representative") of authoritarianism by forcibly resisting attempts at conquest and closing text by the reader. For him, the text remains free, open, and autonomous. The same idea was also conveyed by Farid Esack by understanding the Koran as "progressive revelation". Therefore, to avoid an authoritarian attitude is to remain aware that the text (al-Quran) is "a work that is constantly changing" or "progressive revelation", so that all forms of interpretation and understanding will continue to be active, dynamic and progressive.

One Muslim scholar who tried to offer a methodology for dismantling the interpreter's alignments was Khaled M. Abou El-fadl. With the negotiating hermeneutical concept, it not only reveals what is stored in the text but exposes the interests stored in the text. According to Khaled, the mechanism for understanding the Qur'anic text involves three components, namely; text, Author, and Reader. In the mechanism of understanding, there is one stage called "meaning determination", which is an action to determine the meaning of the text. The stage of "Determination of meaning" is a complex, interactive, dynamic and dialectical process between text, readers, and authors. In this dialogue process, the interpreter has the ability to impose any meaning he wants on a text. At this stage too, sometimes interpreters act arbitrarily.

The arbitrariness of interpreters, according to Khaled, can also occur by opening texts and entering various unlimited meanings. As a result, it cannot be accommodated by the text itself. On the other hand, the possibility can also occur otherwise. The actual text is open for various meanings to enter, but instead insists it is believed that the text can only accommodate a meaning. Therefore, Khaled limited Mufassir's arbitrariness by emphasizing the balance between the intent of the text, the intention (interest) of the reader and the 
intent of the author (God). The connection between interpretation and interest can also be analyzed using Goerg-Hans Gadamer's Philosophical Hermeneutics. According to him, understanding is not an activity carried out consciously and based on human choice when facing an object (text). On the contrary, the human experience becomes a constant provocation for interpretation. "The understanding and interpretation of the text is not a concern of science, but obviously belongs to the human experience of the world in general."

A reader, it is impossible to get an objective or definitive understanding of a text (text) as referred to by author (author) - in this case God - According to Gadamer, this is due to two things; First, Mufassir cannot place himself in the position of the original author of the text to find out the original meaning. Second, understanding is not a mysterious communion of souls where the interpreter grasps the subjective meaning of the text.

According to Hasan Hanafi, Mufassir's partisanship is a necessity. A Mufassir is a reformer who not only understands the Universal meaning of the Qur'an, but also to change the present reality. Interpreting the Qur'an not only explains (auslegen), but also understands (verstehen). Henot only knows (wissen), but even influences consciousness (besinnen). Interpretation not only analyzes, but also synthesizes. Interpretation conflicts are maslahah conflicts, socio-political conflicts, not theoretical conflicts. A Mufassir is a person who lives in socio-political conditions, and is involved in certain problems and benefits. Differences in interpretation are more influenced by differences in maslahah (al-masalih), and differences in al-masalih back to the social structure (at-tarkib lil mujtama ').

In this context, it can be understood that the determination of meaning comes from a complex, interactive, dynamic and dialectical process between the three elements above (text, author and reader). Meanwhile, a reader/ interpreter - in this case a special representative - in reading the text so that there is no misuse of authority must fulfill the "five conditions of authority" as the principles of interpretation that are "responsible". Among other things, honesty, sincerity, totality, rationality, and self-control. On another issue, the fact that the reader/ interpreter is not free of assumptions, then in interpreting it sometimes contradicts the text. In such conditions, the reader/ interpreter must pause accuracy on the text. The purpose of this pause is not to reject the text or reject the stipulation, but to reflect on it and investigate it more deeply. This is similar to highlighting an issue to further study it, and postpone the decision until the study is completed. The essence is nothing but to do a "balance of strength" between the intent of the text, the author and the reader which greatly affects the movement of hermenuetics. 


\section{RELATIONS OF TEXT, AUTHORS AND READERS}

Khaled Abou El Fadl questions text relations, authors and readers from the point of view of the hermeneutical approach. According to Amin Abdullah, a critical religious study through a hermeneutic approach is not so popular and for certain circles, it tends to be avoided. "Instead of using and applying it in academic studies about socio-religious life, hearing the term hermeneutic is already"said Amin Abdullah. Others, said Amin Abdullah, were related to the influence of Biblical Studies in the Christian environment which would be applied in the study of the Koran in an Islamic environment.

In this context, Hujair Sanaky stated that Khaled Abou El Fadl tried to give birth to a critical analysis of the anatomy of authoritarian interpretation of Islamic law with a hermeneutic approach. Abou El Fadl believes that so far "the methodology of authoritarian interpretation" willundermine the integrity of Islamic text and dim its voice and can erode the usefulness and power of Islamic law. After Abou El Fadl identified the anatomy of the discourse of the authority of the text, proposed to uphold the authority of the text and limit the authoritarianism of the reader, which is called "using the power of God" to "justify the arbitrary actions of the reader" in understanding and promoting the text. Abou El Fadl, occupying proportionally the relationship between the text, the author, and the reader in the dynamics of the struggle of Islamic legal thought.

Abou El Fadl, always upholds the authenticity of the Qur'an as the eternal Kalam of Allah and the prophethood of Muhammad as an example. Abou El Fadl questioned whether the verse of the Qur'an is a text that is "open" or "closed" in the process of interpretation. If the text of the Qur'an is open, it will provide opportunities for the emergence of ideas and stimulation of constructive interpretation activities. Conversely, if the Qur'anic text is closed, and aims to limit the antithetical interpretation of the reader. Therefore, Abou El Fadl proposed to continue to uphold the authority of the text and also limit the authoritarianism of the reader. His attitude continues to uphold the Qur'anic text, but he also fully supports honest and rational efforts to explore, study, and model the Qur'an. So according to Abou El Fadl, the Qur'an as a holy and eternal word of God, does not necessarily close or close itself from studies, research, confirmation and criticism.

Through this work, Khaled Abou El Fadl wants to fully make the text of the Qur'an "not anti-criticism". The Qur'an as a sacred text must be open and "not anti-criticism". So, it still exudes its charm of integrity. Abou El Fadl, truly believes the authenticity of the Koran as a holy and eternal word of God, but "does not then confine itself". But, independently can explore and interpret the Kalam Suci (Qur'an). So, to build this openness, Abou El Fadl tried to occupy 
the relationship or relationship between Text (text), Author (author) and Reader (reader) proportionally. In addition, there is also a "negotiating process" between the three. Thus, there is no tragedy of authoritarianism in the dynamics of the struggle of Islamic legal thinking.

In this context, the relationship between the text, the author, and the reader of course, requires language as the symbol system used. When a person or group uses language intermediaries as a medium of communication, dialogue, interpretation or pouring thoughts, it must automatically understand the limitations inherent in it. Text readers will face complex problems to determine to mean. Because the understanding of the text cannot be determined by any group, both authors and readers unilaterally, which can lead to conflict. The understanding text is a product of harmonious and living interactions between authors, texts, and readers. The process of balancing between the various content of interests brought by each party (author, text, reader) and the ongoing negotiation process between the three parties. At this position every "role" must be respected and the role of each party must be considered and not allowed to control, suppress, and dominate the other party in determining the "meaning of the text" that they want to search together.

\section{CONCLUSION}

One of Khaled Abou El Fadl's biggest ideas contributed to the discourse of contemporary Islamic law is to dismantle authoritarianism malpractice in Islamic law. More than that, Khaled also tried to restore the Islamic legal discourse to the initial spirit, which was to reaffirm ijtihad as an effort to exert as strong a human ability to carry out searches, investigations, and understanding of God's Will. In this context, Khaled distinguishes between sharia and fiqh. Syari'ah is the Will of God in an abstract and ideal form, but fiqh is an attempt by humans to understand God's Will. In this sense, sharia is always seen as the best, fair and balanced. While fiqh is only an attempt to achieve the ideals and goals of sharia (maqâshid al-Syarî'ah). The purpose of Islamic law is to realize human benefit (tahqîq mashlih al-'ibâd) and the purpose of fiqh is to understand and apply sharia. This difference is born from the recognition of human failures to understand God's purpose and purpose. In this context, human ijtihad is never final and perfect. All the things, Khaled wants the sharia to be understood in a struggle of discourse that keeps changing and moving forward; progressive fiqh discourse.

\section{BIBLIOGRAPHY}

Abdullah, M. Amin, Islamic Studies di perguruan Tinggi Pendekatan IntegratifInterkonektif (Yogyakarta: Pustaka Pelajar, 2006). 
Studi Agama: Normativitas atau Historisitas? (Yogyakarta: Pustaka Pelajar, 1999).

Auda, Jasser. Maqasid al-Syariah as Philosophy of Islamic Law: A Systems Approach. (London: The International Institute of Islamic Thought, 2008).

Abdullah, Taufik, Ensiklopedia Tematis Dunia Islam, (Jakarta: PT Ikhtiar Baru Van Hoeve, Tahun 2002).

Bakri, Asafri Jaya, Konsep Maqashid Syari'ah menurut al- Syatibi, (Jakarta: P.T. Raja grafindo Persada, 1996).

Djamil, Fathurrahman, Filsafat Hukum Islam, (Jakarta: Logos Wacana Ilmu, 1997).

El Fadl, Khaled Abou, Speaking in God's Name, (Oxford: Oneworld, 2001)

Esack, Farid. Qur'an Liberation \& Pluralism: An Islamic Perspective of Interreligious Solidarity Against Oppression. (Oxford: Oneworld Publications, 1997).

Hidayat, Kamaruddin , Memahami Bahasa Agama: Sebuah Kajian Hermeneutik, (Jakarta: Paramadina, 1996).

Mahfud, Choirul, Politik Pendidikan Islam di Indonesia, (Yogyakarta: Pustaka Pelajar, 2016).

----, The Global and Local Challenges of Islamic Education in Contemporary Indonesia, Scientific Journal of PPI-UKM 3 (2), 5054

Rahmawati, K Yahiji, C Mahfud, J Alfin, M Koiri, Chinese ways of being good Muslim: from the Cheng Hoo Mosque to Islamic education and media literacy, Indonesian Journal of Islam and Muslim Societies 8 (2), 225-252.

Rusli, Nasrun, Konsep Ijtihad Al Syaukani: Relevansinya bagi Pembaruan Hukum Islam di Indonesia, (Jakarta: Logos, 1999).

Safi, Omit. Progressive Muslims: On Justice, Gender, and Pluralism. (Oxford: Oneworld Publications, 2003).

Supriyanto, Didik, Perkembangan Nilai Agama dan Moral Anak dan Pendidikan Keagamaan Orangtua, MODELING: Jurnal Program Studi PGMI 2 (2), 2015: 66-75

--, Pengaruh Penggunaan Media Pembelajaran Berbasis ELearning, MODELING: Jurnal Program Studi PGMI 5 (1), 2018: 112-129

Qattan, Manna' Khalil, Studi Ilmu-Ilmu Qur'an, (Bogor: Pustaka Litera antar Nusa, 2001). 